\title{
A COMPARATIVE STUDY OF TWO GEL-BASED TECHNIQUES TO DETECT THE RELATIONSHIP BETWEEN POST-MORTEM INTERVAL AND NUCLEAR DNA DEGRADATION IN DIFFERENT TISSUES IN ALBINO RATS
}

\author{
Mohamed Abdelrahman Mohamed*, Mahmoud El Sherbeny** and Doaa Abdallah Farag***
}

\begin{abstract}
Background and objective: Postmortem interval (PMI) estimation is an important aim in forensic medicine. An accurate estimation of PMI helps to define the murder time and enable investigators in forensic field especially when they are collecting evidence that can reinforce or exclude the conducts of suspects in a crime. Some techniques were introduced to estimate postmortem interval with the aid of assessment of DNA fragmentation qualitatively and quantitatively. These include Agarose gel and single cell gel electrophoresis or comet assay. It is recommended to select the most appropriate method to overcome the troubles of postmortem DNA degradation.
\end{abstract}

Methodology: 30 adult male Sprague Dawley albino rats were selected in the study. Animals were divided into 5 groups and were drowned at the beginning of the experiment. First group's rats had sacrificed immediately after drowning, whilst the $2^{\text {nd }}, 3 \mathrm{rd}, 4^{\text {th }}$ and $5^{\text {th }}$ groups were sacrificed at $6,12,24$ and 48 hours postmortem respectively. The palatal mucosa and submandibular salivary glands were dissected and extracted for DNA studying and detection. The samples were processed through Agarose gel and single cell gel electrophoresis (comet assay) techniques to estimate the degree of DNA degradation. Results were analyzed statistically and Pearson correlation ( $r$ ) was used to test the association between PMI \& degradation of DNA. Level was considered significant at $\mathrm{p}$ value $\leq 0.05$.

Results: Agarose gel technique revealed variation in DNA degradation ranging from no changes to severe changes with high correlation association between PMI and DNA in palatal mucosa samples but no correlation in samples of submandibular salivary glands. Comet assay results showed high correlation in all samples from both tissues between PMI and both of tail length and tail moment of the degraded DNA.

Conclusion: Comet assay technique is a more reliable and dependable method in determination of early time of death as shown by the statistical analysis than did Agarose gel electrophoresis technique

KEY WORD: Postmortem, Electrophoresis, Agarose gel, Comet assay, Tail length, Tail moment

\footnotetext{
* Associate Professor of Oral Biology, Faculty of Dentistry, Mansoura University, Egypt

** Lecturer of Oral Pathology, Faculty of Dentistry, Mansoura University, Egypt
} 


\section{INTRODUCTION}

Postmortem interval (PMI) estimation is an important aim in forensic medicine. Determination of death time is critical in civil and criminal conditions. An accurate estimation of PMI helps to define the murder time, verify witnesses' statements, reduce the suspects' number and enable the evaluation of their statements. It is also significant for investigators in forensic field especially when they are collecting evidence that can reinforce or exclude the conducts of suspects in a crime, (DiMaio and DiMaio 2001). However, biologically, there are significant differences in some cases. So, the precise death time may not be determined by any way, however a convergent time range can be supposed. The principles of PMI estimation are based on the calculation of extrapolation and return from postmortem change in a certain case to the moment of death. Time elicitation since death always implies an interval not an exact time point, (Madea \& Henssge 2003). In order to compass this trouble, some techniques were introduced to estimate postmortem interval with the aid of DNA fragmentation assessment qualitatively and quantitatively, (Laura and James 2002). These techniques include Agarose gel and single cell gel electrophoresis (SCGE) or called Comet assay.

Agarose gel electrophoresis (AGE) technique is used to separate molecules of biological origin according to their size. The separation of molecules is based on their sizes that can be useful in identification of unknown samples in comparing with known results or performing accuracy during other procedures. AGE is a widely spread technique in separation of DNA molecules and so it is mostly used during the techniques of manipulation of DNA, or researches including individuals identification depending on their unique DNA sequence. After migration of DNA through the gel, it needs to be visualized to estimate the abundance and length of the molecules in the sample. DNA needs to be stained with methylene blue as a colored stain or more frequently with Ethidium bromide which is a fluorescent stain because it is not visible to the naked eye. Fluorescent stains give better results of detection levels when imaging gels, (Yun, John,

\section{Chih-Yuan \& Yong 2012)}

In this context, SCGE or comet assay is a fast precise multipurpose and more cost efficient technique that is particularly can be used for the estimation of DNA fragmentation qualitatively and quantitatively, (Shukla, Bajpayee \& Dhawan 2016). This technique is mainly sensitive and specific in detection both double \& single- stranded DNA breaks and excision repair points in single cells, (Olive, Banath \& Fjell 1994 and Shukla, Bajpayee \& Dhawan 2016). During postmortem autolysis, the organelles inside the cells and DNA of the nucleus break down into their components parts. One of the possible methods that determine postmortem interval is the analysis of DNA, (Boy, Bernitz \& Van Heerden 2003). Determination of DNA quantity must be an impartial and accurate method for estimation the postmortem interval, (Liu et al 2001). So, it is recommended to select the most appropriate organ for extraction of DNA and also to realize the influence of postmortem interval on degradation of DNA, (El-Harouny, El-Dakroory, Attalla, Hasan, Hassab El-Nabi 2008).

According to the above mentioned, this research was conducted to compare and assess the most dependable and reliable method between two gel based electrophoresis techniques in determining the correlation between degradation of DNA and postmortem interval.

\section{Animals and methodology:}

This study included 30 adult healthy male Sprague Dawley albino rats housed in the Nile Center for Experimental Research (NCER), Mansoura, Egypt. 
It was approved by the ethical committee of the Faculty of Dentistry, Mansoura University, Egypt with registration number A14091019. Animals were classified into 5 groups. They were drowned (as a method of inducing death) at the beginning of the experiment. First group's rats were sacrificed immediately after drowning, whilst the second, third, fourth and fifth groups had been sacrificed at $6,12,24$ and 48 hours postmortem respectively and the palatal mucosa and submandibular salivary glands were dissected and extracted. DNA of the tissues was studied and detected by:

1. Agarose gel electrophoresis: DNA quantity was measured by detecting its volume intensity through image analysis program. This technique was conducted in the molecular biology unit at the Nile Center for Experimental Research (NCER), Mansoura, Egypt.

2. Single cell gel electrophoresis (Comet assay): Frozen samples subjected to biochemical processes for detecting DNA single strand break cross-linking with approach similar to cytogenetic assays. The procedure was conducted at the Animal Reproduction Health Research Institute, Giza, Egypt. The resulted image appeared as comets having a central circular shape(head region) that contain most of the intact long stranded DNA remaining in the nucleus while the tail contains fragmented DNA, (Ritesh 2017).

\section{Method of DNA studying:}

1- Agarose gel electrophoresis (Agarose GE): Chemicals, Equipments, Gel preparation and DNA extraction and purification: according to the manufacturing instructions, QIAGEN Sample and Assay Technologies. (QIAamp ${ }^{\mathrm{R}}$ DNA Mini Kit (50)), Cat. No. 51304 for Molecular Biology, QIAamp DNA Mini and Blood Mini Handbook 05/2016, www.qiagen.com.
Electrophoresis: Performed for 2 hours at 50 volt in gel buffer ( $1 \mathrm{X}$ Tris Borate EDTA) at room temperature. The level of the buffer was $2 \mathrm{~mm}$ covering the gel. Photographing the gel was performed using BIO RAD molecular imager ${ }^{(\mathrm{R})}$ Gel DOC ${ }^{\mathrm{TM}}$ $\mathrm{XR}+$ with image lab software. BIO RAD, Model No: Universal Hood II, Serial No: 721BR07403, Input, 100/115/230 V. F1-F2 Fuses type T2A. Max rated power $200 \mathrm{VA}$, Frequency 50/60 Hz. (Bio-Rad laboratories, Inc. www.bio-rad.com .

2- Comet assay technique: include preparation of Reagents (materials and procedures), slides preparation for Comet Assay (Preparation of base slides and Cell isolation / treatment) and Electrophoresis of Microgel slides, (Singh, McCoy, Tice \& Schneider 1988, Kassie Parzefall \& Knasmuller 2000 and Tice et al 2000), Dhawan, Mathur \& Seth 2002 and Alok et al 2002).

Evaluation of DNA damage in Comet assay technique: To visualize damage of DNA, examinations were occurred on (Ethidium Bromide) EtBr-stained DNA using a 40x objective on a fluorescent microscope using a Komet 5 image analysis software developed by Kinetic Imaging, Ltd. (Liverpool, UK) linked to a CCD camera to value the degree of damage of DNA in the cells quantitatively and qualitatively by measuring the length of migration of DNA and the percentage of migrated DNA. Finally, the program calculates tail moment. In general, 50-100 selected cells (randomly) were analyzed per sample. The recorded comet parameters are tail moment, tail DNA (\%) and tail length as shown in Fig 6. These three parameters of SCGE assay are defined as:

Tail Moment $=$ Tail Length $\mathrm{x} \%$ DNA Tail. Tail Length $=$ length of migrated DNA from the nuclear core. It is used to estimate the degree of DNA damage. $\%$ Tail DNA $=$ the fraction of total DNA present in tail of migrated DNA, (Ritesh 2018). 


\section{Statistical Analysis:}

The results were analyzed statistically using SPSS program version 17. Mean, median and standard deviation were calculated, Pearson correlation (r) was used to test the association between PMI \& degradation of DNA. Level of significance is at $p$ value $\leq 0.05$.

\section{RESULTS}

\section{1-Agarose gel electrophoresis:}

* DNA fragmentation assay in palatal mucosa (Plate 1 curve in figure 2); Following separation, the fragments of DNA could be seen as well defined bands. There was intact DNA at zero time, moderate DNA damage at $6 \mathrm{~h}$, mild damage of DNA at $12 \mathrm{~h}$ postmortem, intense damage of DNA at $24 \& 48 \mathrm{~h}$ postmortem. Table (1) shows comparison of volume intensity of DNA of palatal mucosa at various postmortem intervals. Fragmentation of DNA (character of apoptosis), was detected by the DNA ladder assay. Regular degradation of DNA could be observed through the gradual lowering in values of DNA volume intensity.

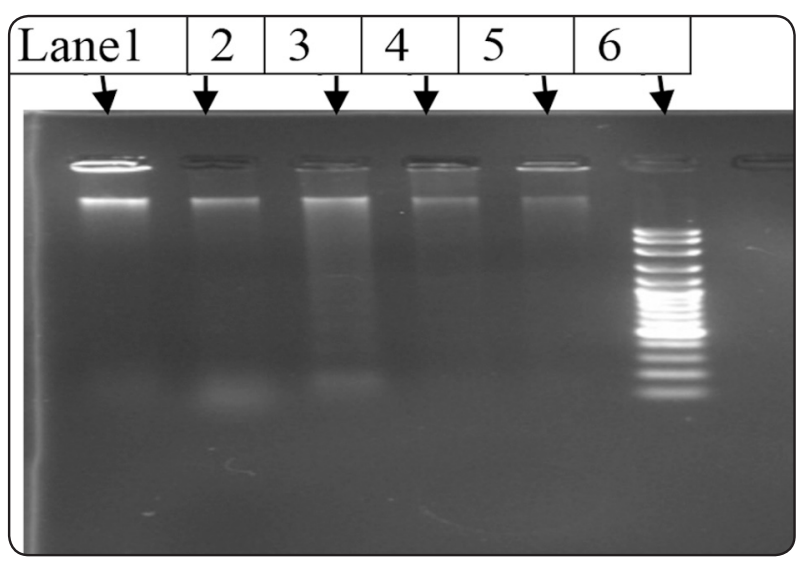

Plate (1): Agarose gel of DNA extracted from Palatal mucosa at various postmortem intervals
* DNA fragmentation assay in submandibular salivary gland (Plate 2 curve in figure 3); Intact DNA at zero time, mild damage of DNA at $6 \mathrm{~h}$, moderate damage of DNA at $12 \mathrm{~h}$ postmortem, moderate damage of DNA at $24 \& 48 \mathrm{~h}$ postmortem. Table (2) shows comparison of volume intensity of salivary gland DNA at various postmortem intervals. The most noticeable findings in the table 2 is the irregular degradation and irregular values of volume intensity of DNA.

At zero hour, most of palatal mucosa and salivary gland cells showed a comet with full head that is rounded in shape with a smaller tail. After 6 hours, the tail length (in micron) and tail concentration (\%) are progressively increased. Cells of palatal mucosa \& salivary glands exhibited increase in the rate of DNA degradation (comet-like cells frequency) and in parameters of DNA changes (length, percentage and moment of tail). This increase is accompanied by the increase in PMI, whilst a decrease in head radius, percentage of head DNA and head area could be noticed (un-tailed DNA, tables 3,4 ). In both samples and in postmortem interval from 0-48 hours, fragmentation was observed by the variation in the shape of comet that could be seen in figures 4,5 .

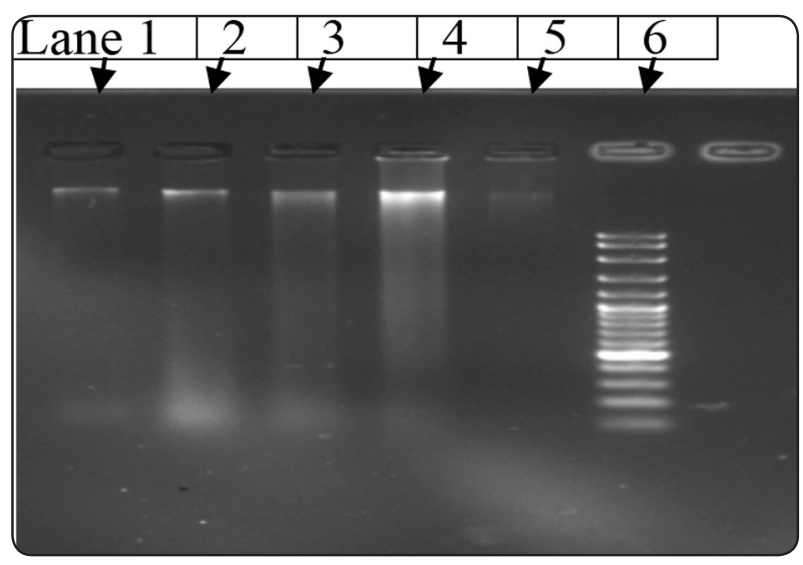

Plate (2): Agarose gel of DNA extracted from Submandibular salivary gland at various postmortem intervals
Lane 1: at zero time of death (control)

Lane 4: 24 hours PM
Lane 2: 6 hours PM

Lane 5: 48 hours PM
Lane 3: 12 hours PM

Lane 6: Ladder (DNA standard) 


\section{Lane and Band Analysis of Agarose gel electrophoresis:}

\section{Palatal mucosa:}

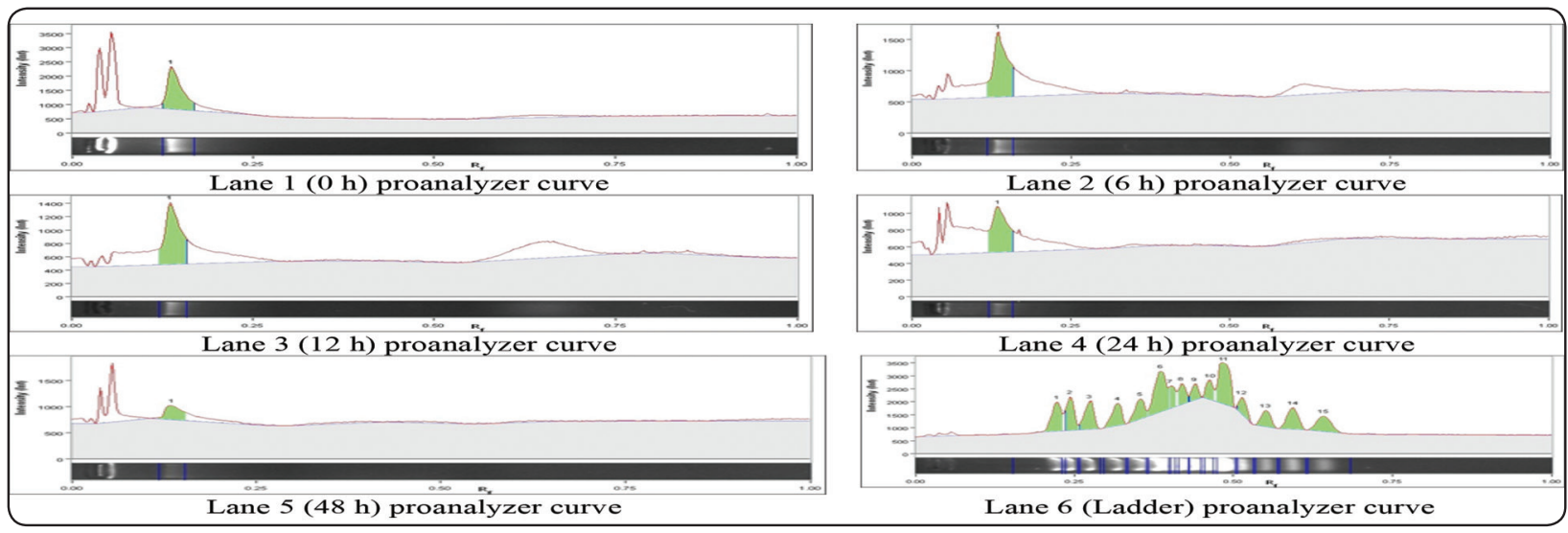

Fig. (2) Computer charts showing DNA volume intensity related to the molecular weight of base pairs in palatal mucosa at different postmortem intervals

TABLE (1): Comparing of volume intensity of palatal mucosa DNA at various postmortem intervals

\begin{tabular}{|c|c|c|c|c|c|c|c|}
\hline Band No. & Base Pairs(bp) & Relative Front & Volume (Int) & Abs. Quant. & Rel. Quant. & Band \% & Lane $\%$ \\
\hline PMI (0 h) & $3,000,0$ & 0.14207 & 529.568 & N/A & N/A & 100 & 31.6 \\
\hline PMI (6 hs) & 3.000 .0 & 0.138 & 349.058 & N/A & N/A & 100.0 & 27.0 \\
\hline PMI (12 hs) & 3.000 .0 & 0.138 & 421.876 & N/A & N/A & 100.0 & 31.6 \\
\hline PMI (24 hs) & 3.000 .0 & 0.138 & 264.696 & N/A & N/A & 100.0 & 23.5 \\
\hline PMI (48 hs) & 3.000 .0 & 0.138 & 93.058 & N/A & N/A & 100.0 & 15.7 \\
\hline Ladder band 1 & 3.000 .0 & 0.225 & 282.42 & N/A & N/A & 8.2 & 7.8 \\
\hline Ladder band 2 & 2.005 .0 & 0.245 & 261.86 & N/A & N/A & 7.6 & 7.3 \\
\hline Ladder band 3 & 2.00 & 0.275 & 266.77 & N/A & N/A & 7.7 & 7.4 \\
\hline Ladder band 4 & 1.005 & 0.320 & 214.96 & N/A & N/A & 6.2 & 6 \\
\hline Ladder band 5 & 1.002 & 0.355 & 192.6 & N/A & N/A & 5.6 & 5.3 \\
\hline Ladder band 6 & 100 & 0.388 & 508.17 & N/A & N/A & 14.7 & 14.1 \\
\hline Ladder band 7 & 900 & 0.403 & 111.888 & N/A & N/A & 3.2 & 3.1 \\
\hline Ladder band 8 & 800 & 0.420 & 147.09 & N/A & N/A & 4.3 & 4.1 \\
\hline Ladder band 9 & 700 & 0.440 & 108.36 & N/A & N/A & 3.1 & 3 \\
\hline Ladder band 10 & 600 & 0.465 & 135.04 & N/A & N/A & 3.9 & 3.7 \\
\hline
\end{tabular}




\section{Salivary glands:}

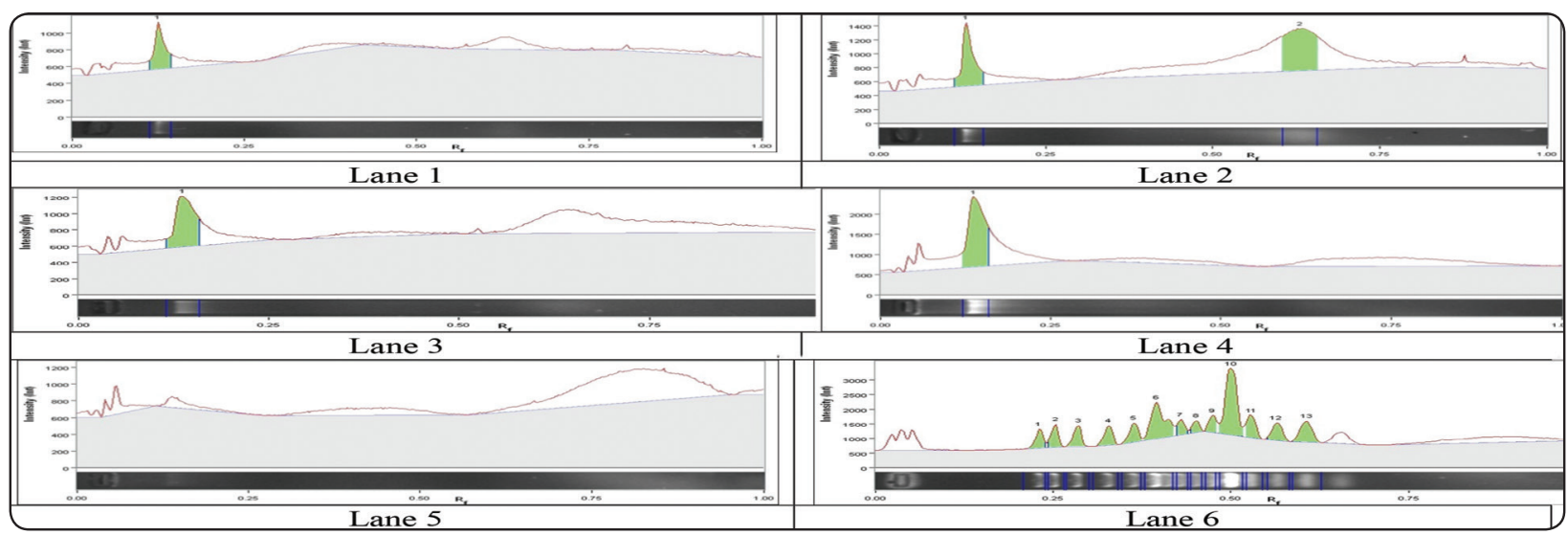

Fig. (3) Computer charts DNA volume intensity related to the molecular weight of base pairs in salivary glands at different postmortem intervals

TABLE (2): Comparing of volume intensity of salivary glands DNA at various postmortem intervals

\begin{tabular}{|c|c|c|c|c|c|c|c|}
\hline Band No. & Base Pairs (bp) & $\begin{array}{l}\text { Relative } \\
\text { Front }\end{array}$ & Volume (Int) & Abs. Quant. & Rel. Quant. & Band $\%$ & Lane $\%$ \\
\hline PMI (0 h) & 2.000 .0 & 0.128 & 142.918 & N/A & N/A & 100.0 & 18.6 \\
\hline PMI (6 hs) & 2.000 .0 & 0.133 & 271.548 & N/A & $\mathrm{N} / \mathrm{A}$ & 36.6 & 11.2 \\
\hline PMI (12 hs) & 2.000 .0 & 0.140 & 293.930 & N/A & $\mathrm{N} / \mathrm{A}$ & 100.0 & 18.3 \\
\hline PMI (24 hs) & 2.000 .0 & 0.140 & 698.180 & N/A & $\mathrm{N} / \mathrm{A}$ & 100.0 & 27.8 \\
\hline PMI (48 hs) & 3.000 .0 & 0.163 & 222.184 & N/A & $\mathrm{N} / \mathrm{A}$ & 100.0 & 21.0 \\
\hline Ladder band 1 & 2.000 .0 & 0.041 & 896.081 & N/A & $\mathrm{N} / \mathrm{A}$ & 001.0 & 27.8 \\
\hline Ladder band 2 & 2 & 0.233 & 121.27 & N/A & $\mathrm{N} / \mathrm{A}$ & 4.8 & 3.4 \\
\hline Ladder band 3 & 1.5 & 0.255 & 135.753 & N/A & $\mathrm{N} / \mathrm{A}$ & 5.3 & 3.8 \\
\hline Ladder band 4 & 1.2 & 0.278 & 137.677 & N/A & N/A & 5.4 & 3.8 \\
\hline Ladder band 5 & 1 & .0330 & 138.75 & N/A & N/A & 5.4 & 3.9 \\
\hline Ladder band 6 & 900 & 0.365 & 140.97 & N/A & N/A & 5.5 & 3.9 \\
\hline Ladder band 7 & 800 & 0.398 & 418.137 & N/A & $\mathrm{N} / \mathrm{A}$ & 16.4 & 11.6 \\
\hline Ladder band 8 & 700 & 0.430 & 96.422 & N/A & $\mathrm{N} / \mathrm{A}$ & 3.8 & 2.7 \\
\hline Ladder band 9 & 600 & 0.453 & 68.931 & N/A & $\mathrm{N} / \mathrm{A}$ & 2.7 & 1.9 \\
\hline Ladder band 10 & 500 & 0.475 & 100.15 & N/A & N/A & 3.9 & 2.8 \\
\hline
\end{tabular}




\section{SCGE (Comet assay) results:}

\section{Palatal mucosa:}
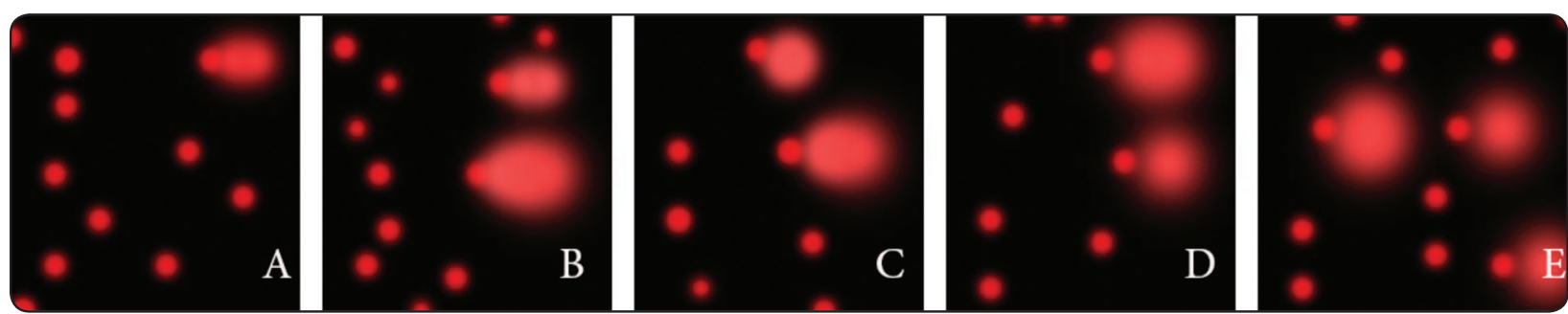

Fig. (4) SCGE of palatal mucosa cells sampled at different PMI from 0-48 h exhibiting increase in the formation of comet tail with prolongation of PMI. The slides are EtBr-stained using a 40x objective on a fluorescent microscope.

TABLE (3) Changes in parameters of DNA in palatal mucosa at various postmortem intervals

\begin{tabular}{|c|c|c|c|c|c|c|}
\hline & Palatal mucosa & Tailed & Untailed & Tail length & Tail DNA & Tail Moment \\
\hline PMI & Sample No & $\%$ & $\%$ & $\mu \mathrm{m}$ & $\%$ & Unit \\
\hline $0 \mathrm{~h}$ & $\mathrm{~A}$ & 3 & 97 & 1.38 & 1.45 & 2.00 \\
\hline $6 \mathrm{hrs}$ & $\mathrm{B}$ & 4 & 96 & 1.46 & 1.52 & 2.22 \\
\hline $12 \mathrm{hrs}$ & $\mathrm{C}$ & 8 & 92 & 1.56 & 1.71 & 2.67 \\
\hline $24 \mathrm{hrs}$ & $\mathrm{D}$ & 10 & 90 & 1.83 & 2.05 & 3.24 \\
\hline $48 \mathrm{hrs}$ & $\mathrm{E}$ & 14 & 86 & 2.24 & 4.59 \\
\hline
\end{tabular}

\section{Salivary gland:}

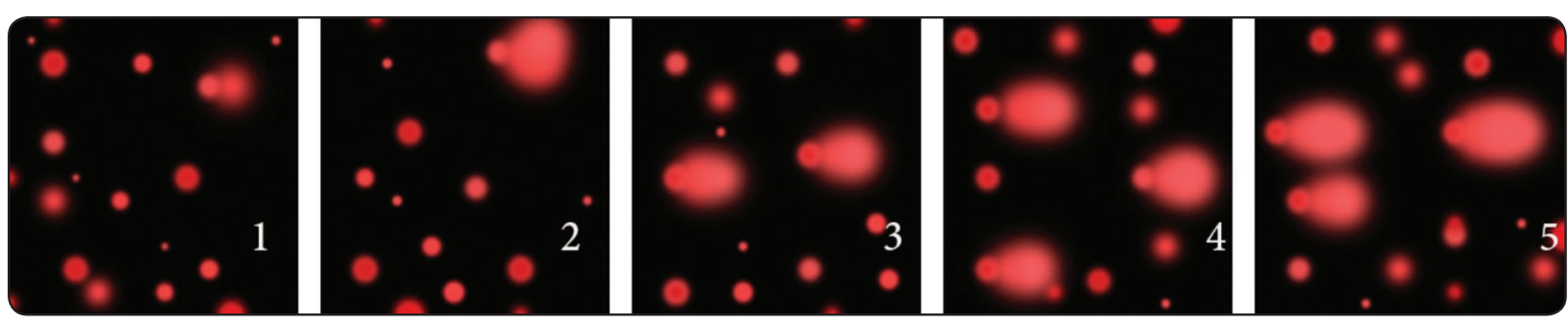

Fig. (5) SCGE of salivary gland cells sampled at different PMI from 0-48 h exhibiting increase in the formation of comet tail with prolongation of PMI. The slides are EtBr-stained using a 40x objective on a fluorescent microscope.

TABLE (4) Changes in parameters of DNA in salivary glands at various postmortem intervals

\begin{tabular}{|c|c|c|c|c|c|c|}
\hline & Salivary gland & Tailed & Untailed & Tail length & Tail DNA & Tail Moment \\
\hline PMI & Sample NO & $\%$ & $\%$ & $\mu \mathrm{m}$ & $\%$ & Unit \\
\hline $0 \mathrm{~h}$ & 1 & 2 & 98 & 1.05 & 0.92 & 0.97 \\
\hline $6 \mathrm{hs}$ & 2 & 3 & 97 & 1.23 & 1.12 & 1.38 \\
\hline $12 \mathrm{hs}$ & 3 & 5 & 95 & 1.38 & 1.23 & 1.70 \\
\hline $24 \mathrm{hs}$ & 4 & 8 & 92 & 1.42 & 1.34 & 1.90 \\
\hline $48 \mathrm{hs}$ & 5 & 11 & 89 & 1.55 & 1.46 & 2.26 \\
\hline
\end{tabular}




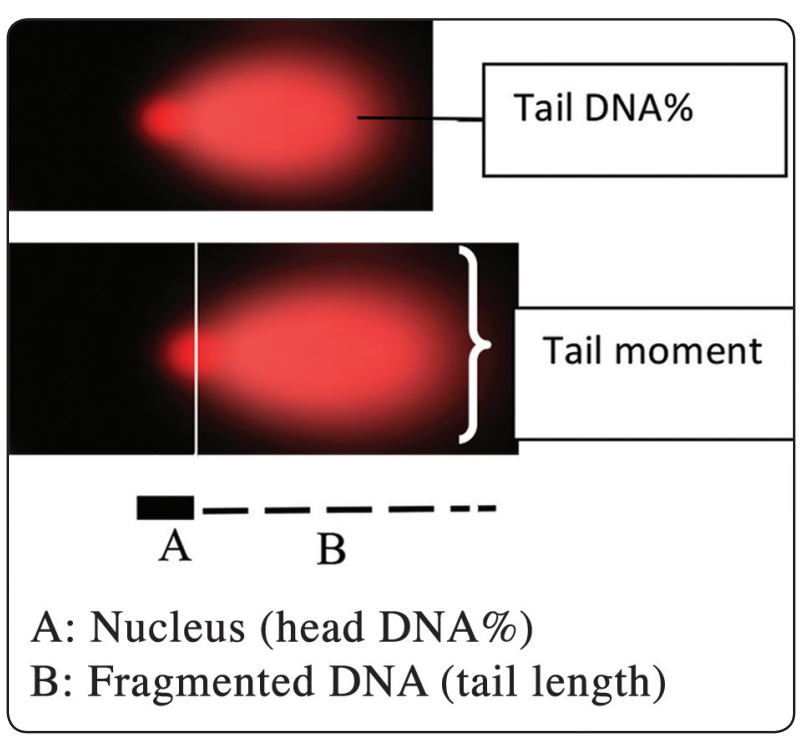

Fig. (6) parameters for assessment of DNA fragmentation

\section{Statistical results:}

As illustrated in table 5, 6 a quantitative analysis of DNA fragmentation related to PMI exhibits a highly positive correlation between DNA fragmentation and increase in time since death in palatal and salivary tail length $\&$ moment $(\mathrm{r}=0.98,0.98,0.98$, and 0.97 respectively and $\mathrm{p}$ value $\leq 0.0001)$. The comet-tail-moment \&length exhibit nearly linear relationship that rises with postmortem interval. Correlation analysis shows that frequency of all comet parameters gives more positive correlation with postmortem interval in palatal mucosa \& salivary gland samples. However, in Agarose gel technique the volume intensity in palatal mucosa is highly negatively correlated with PMI, Pearson correlation $r=-0.93$, (that means volume intensity of DNA decrease with increase in time since death) whilst there is no correlation in salivary DNA volume intensity $(\mathrm{r}=0$ and $\mathrm{p}=1)$.
TABLE (5): Descriptive statistics

\begin{tabular}{|l|c|c|}
\hline Measure n=30 & $\begin{array}{c}\text { Mean } \\
(\mathrm{SD})\end{array}$ & $\begin{array}{c}\text { Median } \\
\text { (Range) }\end{array}$ \\
\hline Comet assay & \multicolumn{2}{|l|}{} \\
\hline Palatal tail length & $1.7 \pm 0.3$ & \\
\hline Palatal tail moment & $3 \pm 0.9$ & \\
\hline Salivary tail length & $1.3 \pm 0.2$ & \\
\hline Salivary tail moment & $1.6 \pm 0.4$ & \\
\hline Agarose gel electrophoresis & & \\
\hline Palatal DNA intensity & & $347.5(90-532)$ \\
\hline Salivary DNA intensity & & $271(98-373)$ \\
\hline
\end{tabular}

TABLE (6): Correlation between PMI and different measures in Comet and Agarose technique:

\begin{tabular}{|l|c|c|}
\hline Measure n=30 & r & p value \\
\hline Comet assay & \multicolumn{2}{|c|}{} \\
\hline Palatal tail length & 0.98 & $<0.0001$ \\
\hline Palatal tail moment & 0.98 & $<0.0001$ \\
\hline Salivary tail length & 0.98 & $<0.0001$ \\
\hline Salivary tail moment & 0.97 & $<0.0001$ \\
\hline Agarose gel electrophoresis & & \\
\hline Palatal DNA volume intensity & -0.93 & $<0.0001$ \\
\hline Salivary DNA volume intensity & 0 & 1 \\
\hline
\end{tabular}

\section{DISCUSSION}

The post-mortem period is the elapsed time between the person death and the time of an autopsy. Although it is not possible to accurately estimate the time of death according to the autopsy results alone, a convenient set of postmortem interval can be deduced by clever interpretation of the different post-mortem changes, (Chandrakanth, Kanchan, Balaraj, Virupaksha, \& Chandrashekar 2013). 


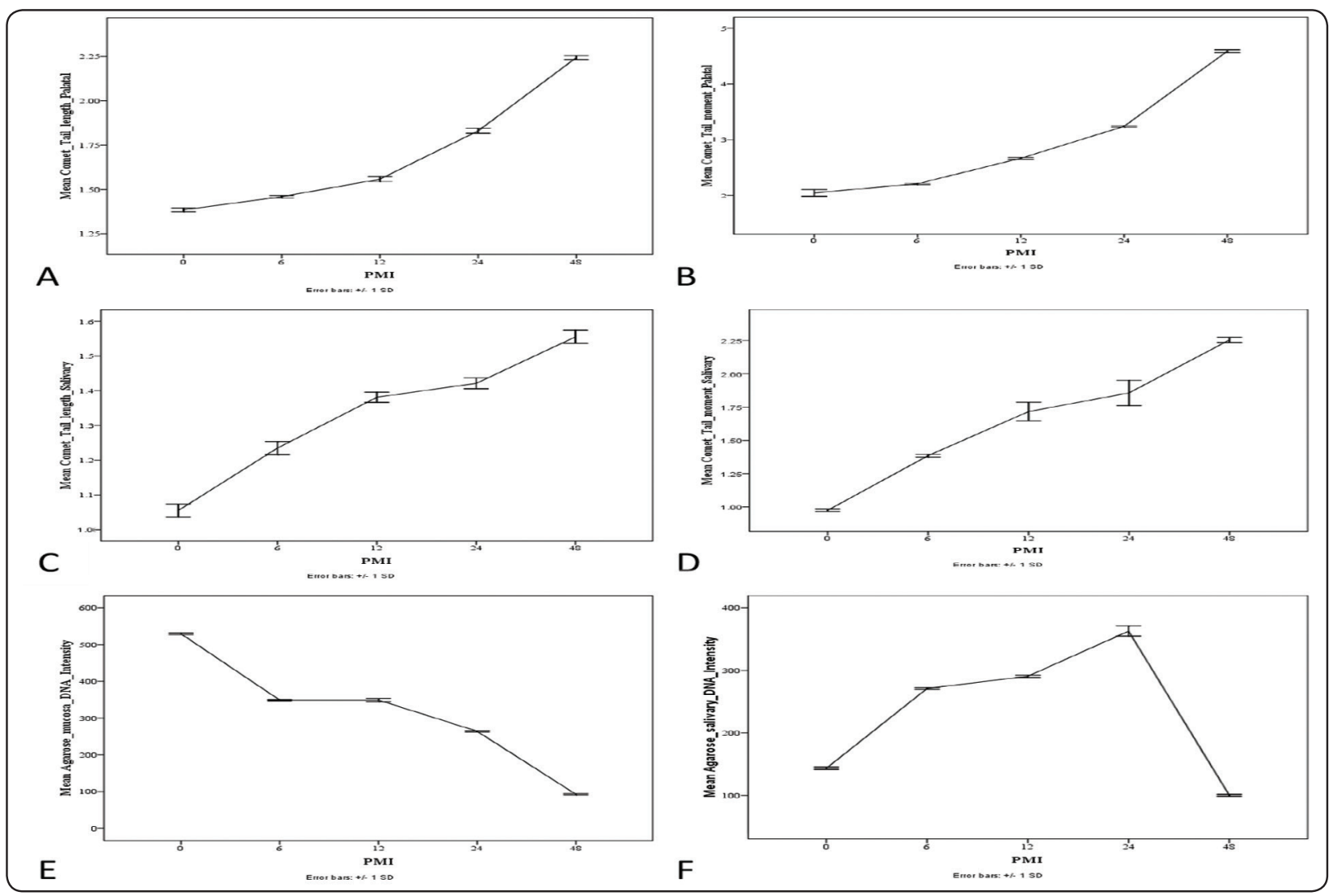

A: Comet-tail length in palate

B: Comet-tail moment in palate

C: Comet-tail length in salivary gland

D: Comet-tail moment in salivary gland

E: Agarose palatal DNA volume intensity

F: Agarose salivary gland DNA volume intensity

Fig. (7) Line chart showing correlation between DNA degradation and postmortem interval (PMI) in palatal mucosa and salivary gland at different time points.

Other branches of forensic science will be affected by the future of DNA forensic. It is important to know that DNA has a significant role in the process of biological identification of a person that is considered a final stage in criminal investigation. Deterioration of biological samples may be considered a popular problem in forensic science that negatively influences interpretation of the result in the investigation procedures. The results obtained from the deteriorated samples would always be doubtful in the court. In this case, comet assay technique may have an important role and can be used as a screening method and prophylactic tool, (Ritesh 2017).
The technique of Agarose gel electrophoresis is an active and effective method of nucleic acids separation. The accurate sizes of detached DNA fractions can be determined by plotting the log of the molecular weight for the various bands of a DNA standard against the distance traveled by each band. The DNA standard contains a mixture of DNA fragments of pre-determined sizes that can be compared against the unknown DNA samples, (Pei,

\section{John, Chih-Yuan \&Yong 2012).}

Comet assay or alkaline SCGE is a quick, sensible and simple technique to assess genotoxicity by quantifying the DNA damage amount brought about in individual cells, (Shoeiba \& Rafath 2018). It is 
well known that when an organism die, the cellular nucleases can fragment DNA and this fragmentation increases with time. This technique is based on the relay of destroyed/decomposed DNA. When DNA is damaged, its molecules can migrate more easily in an electric field in comparison with intact molecules, (Olive, Banath \& Fjell 1994).

Two tissues were selected for this research as an example of the oral and paraoral structures, palatal oral mucous membrane and the submandibular salivary gland. Both of them could be considered protected as they are completely enveloped by the surrounding bone, muscles, fascia and skin hence become away from environmental deteriorating conditions. So, they are suitable for the aim of the experiment.

The results of comet assay technique (parameters, in table 3,4 ) showed statistical significant difference where they are highly correlated with postmortem interval using linear correlation method. Comparable results also noticed by $\mathbf{L i n}$ et al 2000, who found DNA degradation rate of liver cells was linearly related to the early PM period. Chen, Shen \& Gu 2005 as well said, DNA amount from kidney, heart and liver cells had deteriorated early in the first postmortem 6 hours indicating a linear relationship between PMI interval and DNA fragmentation.

These observations come in accordance with (Zhen, Zhang \& Niu 2006) and (Luo et al 2006). They reported that fragmentation of DNA observed in the form of increase in comet tail is associated with PMI prolongation. Furthermore, Hao et al 2007 concluded that fragmentation of DNA could be induced with time-dependent manner using comet assay at various postmortem interval (0-24 h) in the cells of liver and brain in rats. Comparable findings also noticed by (Gomaa, El-Khalek \& Sameer 2013) which found that fragmentation of DNA increased with PMI prolongation (3-24 h) in samples of liver and brain. The present study showed a high correlation between PMI and comet parameters through linear correlation analysis.
This comes in accordance with the study done by (Zheng, Li \& Shan et al 2012). They studied DNA fragmentation in dental pulp and brain cells of the mouse using comet assay for long periods after death reaching up to $72 \mathrm{~h}$. Their study revealed a high correlation between comet parameters and PMI through linear regression analysis.

In the study done by (Ritesh 2017), it had been designed to prolong the PMI from 0 to 56 h. They found an increase in fragmentation of DNA observed in comet assay parameters. These findings supported comet assay as a more precise, dependable and appropriate technique which could be used as an encouraging way along with other traditional methods for estimation of PMI.

However, the results of the present study contradict with the study done by (Laura and James 2002), which showed increase fragmentation of DNA from 3-56 h postmortem and increase tail length and moment. After $56 \mathrm{~h}$, the image of comet did not show any significant changes suggesting no further DNA fragmentation could be detected which may be due to the higher level of DNA fragmentation or the limit of sensitivity of this particular method. The point of contradiction here, in the present study, is the observation of DNA degradation is parallel with the prolongation of PMI in a regular manner not intermittently but in Laura and James 2002's study the degradation was not observed after $56 \mathrm{~h}$.

Tables of Agarose technique referred to an irregular increase in degradation of DNA and there is a great variability and wide range in the figures of volume intensity at different PMI. For example, the palatal values of volume intensity of DNA at 0 , 24 and $48 \mathrm{~h}$ postmortem are 529.568, 264.696 and 93.058 respectively whilst the values in salivary glands are 142.918, 698.180 and 222.184 at the same postmortem intervals. With this great and wide range between figures we use median in the descriptive statistics instead of mean. Also, the analysis of correlation in palatal mucosa showed $(\mathrm{r}=-0.93)$ while 0 in salivary tissues (no correlation) 
although both of the tissues exhibited high correlation in comet technique.

This could be interpreted by the high degree of sensitivity of Agarose gel technique that may be affected by other factors such as concentration of the gel, temperature, duration and electric current passing through the electrodes. These observations agree with the results of (Ritesh 2017) in his experiment. He noticed the differences in his results and revealed that biological samples subjected to some conditions such as alkylation, radiation, and fenton reaction can alter the chemical structure of DNA that can simultaneously stimulate un-repairable fragmentation in DNA strands. Also, the rate of degradation of DNA differs in various tissues (Liver, kidney and spleen) and in samples from different organisms (rat or human), (Chengzhi et al 2016).

For example, human brain is not subjected to direct injury by extrusion due to the protection of hard skull, and the microorganisms invasion is far away from intestines and body surface. Accordingly, the great variation in DNA volume intensity of PMI $12 \mathrm{~h}$ in palatal mucosa and PMI $6 \mathrm{~h}$ in salivary gland samples in Agarose technique can be attributed to the nature of materials of both tissues where they are derived from different organs and differs in the liability of electric current passing through the electrodes. The using of samples from different organs at the same time has some advantages, (Shu et al 2005). Generally, the longer the time of death has occurred, the less accurate the PMI estimate would be, (Teo, Noor, Hing, Sri \&Albakri 2014).

\section{CONCLUSION AND RECOMMENDATION}

According to the above discussed findings, SCGE (comet assay technique) provide a more reliable and dependable method in determination of time of death as shown by the statistical analysis and validity of the results. So, this method can be used with other conventional methods for a reliable and sensitive analysis of PMI. Most of degradation took place early in $0-24 \mathrm{~h}$ postmortem period so represent a more rapid rate of DNA degradation than late time point.

Further experiments with shorter or longer intervals should reveal whether there is a cause for this large change or whether it occurred by increased degradation rate which is present over the first $24 \mathrm{~h}$ postmortem. . It is also recommended to study DNA degradation in cases with different causes of death, in multiple tissues and with different techniques to investigate which one is much better in discovering the cause of death and its effect on DNA degradation rate.

\section{REFERENCES}

1. Albertini R, Anderson D, Douglas G, Hagmar L, Hemminki K, Merlo F, Natarajan A and Norppa H et al. IPCS guidelines for the monitoring of genotoxic effects of carcinogens in humans. Mutat Res 2000; 463: 111-172.

2. Aljanabi S. M. and Martinez L. Universal and rapid salt extraction of high quality genomic DNA for PCR based techniques. Nucl Acids Res 1997; 25: 4692 - 4693.

3. Alok D, Diana A, de Pascual ST, Celentino S-Buelga, Michael N C and Costas I: Evaluation of the antigenotoxic potential of monomeric, dimeric and black tea polyphenolics against heterocyclic amine-induced DNA damage in human lymphocytes using the comet assay. Mutat. Res 2002; 515: 39-56.

4. Boy S, Bernitz H, Van Heerden W. Flow cytometric evaluation of postmortem pulp DNA degradation. Am J Forensic Med Pathol. 2003; 24 (2): 123- 127.

5. Chandrakanth, H.V, Kanchan, T, Balaraj, B.M., Virupaksha, H.S. and Chandrashekar, T.N. Postmortem vitreous chemistry. An evaluation of sodium, potassium and chloride levels in estimation of time since death (during the first $36 \mathrm{~h}$ after death). Journal of Forensic and Legal Medicine 2013; 20(4): 211-216.

6. Chen X, Shen YW, Gu YJ. The research of relationship between DNA degradation and post-mortem interval. Fa Yi Xue Za Zhi 2005; 21:115-117.

7. Chengzhi L, Qi W, Yinming Z, Hancheng L, Ji Z, Ping H and Zhenyuan W. Research progress in the estimation of the postmortem interval by Chinese Forensic scholars. Forensic Sciences Research 2016; 1(1): 3-13. 
8. Dhawan A, Mathur N and Seth. The effect of smoking and eating habits on DNA damage in Indian population as measured in the comet assay. Mutat Res 2002; 474:121-128.

9. DiMaio V and DiMaio D. Forensic pathology. 2nd ed. Boca Raton: CRC Press LCC; 2001, p. 21-42.

10. Madea B, Henssge C. Timing of death. In: Payne-James J, Busuttil W, Smock W, editors. Forensic medicine: clinical and pathological aspects. London: Greenwich Medical Media Ltd.; 2003. p. 91-114.

11. El-Harouny M, El-Dakroory S, Attalla S, Hasan N, Hassab El-Nabi S. The Relationship between Postmortem Interval and DNA Degradation In Different Tissues Of Drowned Rats. Mansoura J. Forensic Med. Clin. Toxicol 2008:16(4); 45-61.

12. Gomaa Mie S, El-Khalek A M A and Sameer M M. The relationship between the postmortem interval and the DNA degradation in brain and liver of adult albino rats. J Am Sci. 2013; 9:535-540.

13. Hao L, Deng S X, Zhao X . Recent advancement in relationship between DNA degradation and postmortem interval. Fa Yi Xue Za Zhi 2007; 23:145-147.

14. Hassab El-Naby, S. Molecular and cytogenetic studies on the anti-mutagenic potential of eugenol in human lymphocytes culture treated with depakine and apetryl drugs. J Egypt Ger Soc Zool (2004); 43C: Histology \&Histochemistry: 171 - 196.

15. Kassie F, Parzefall W, Knasmuller S. Single cell gel electrophoresis assay: A new technique for human biomonitoring studies. Mutat Res.2000; 463; 13-31.

16. Laura A Johnson and James A.J Ferris .Analysis of postmortem degradation by single cell gel electrophoresis. Forensic Science International 2002; 126: 43-47.

17. Liu L, Peng D, Liu Y, Deng WN, Liu Y and Li J: A study on the relationship between postmortem interval and the changes of DNA content in the kidney cellule of rat. Fa Yi Xue Za Zhi 2001; 17(2): $65-68$.

18. Lin L, Liu L, Deng W, et al. An experimental study on the relationship between the estimation of early post-mortem interval and DNA content of liver cells in rats by image analysis. Fa Yi Xue Za Zhi 2000; 16:68-69.

19. Luo G, Chen Y and Cheng J , et al. Relationship between DNA degeneration and postmortem interval of corrupt corpse. Fa Yi Xue Za Zhi. 2006; 22:7-9.

20. Madea B, Henssge C. Timing of death. In: Payne-James J, Busuttil W, Smock W, editors. Forensic medicine: clinical and pathological aspects. London: Greenwich Medical Media Ltd.; 2003. p. 91-114.
21. Olive P, Banath J and Fjell C. DNA strand breakage and DNA structure influence staining with propidium iodide using the alkaline comet assay. Cytometry. 1994; 16:305-312.

22. Pei YL, John C, Chih-Yuan H, Yong H : Agarose Gel Electrophoresis for the Separation of DNA Fragments Journal of Visualized Experiments (62),e3923, doi:10.3791/3923 (2012).

23. Ritesh K. Forensic application of comet assay: An emerging technique. Forensic Sciences Research 2017;2(4): 180-184.

24. Ritesh K. An introduction to the single cell gel electrophoresis assay: a technique resolving issues in forensic science. Egyptian Journal of Forensic Sciences 2018; 8:1.

25. Rojas, J. Ryu, Y. Sasaki: Single cell gel/ Comet Assay: Guidelines for in vitro and in vivo genetic toxicology testing. Environ. Mol. Mutagen 2000; 35: 206-221.

26. Shoeiba T and Rafath Y. Evaluation of genotoxicity by comet assay (single-cell gel electrophoresis) in tissues of the fish Cyprinuscarpio during sub-lethal exposure to Karanjin. The Journal of Basic and Applied Zoology 2018; 79:19

27. Shukla R, Bajpayee M and Dhawan A. Detection of DNA damage in different organs of the mouse. Comet Assay Toxicol. 2016; 30:164-176.

28. Shu X, Liu Y, Ren L, Fanggang HE, Zohu H, Liu L, Liu L. Correlative analysis on the relationship between PMI and DNA degradation of cell nucleus in human different tissues. $\mathrm{J}$ of Huazhong University of Science and Technology. 2005; 25(4): 423-426.

29. Singh N, McCoy M, Tice R and Schneider E: A simple technique for quantitation of low levels of DNA damage in individual cells. Exp. Cell Res 1988; 175: 184-191.

30. Teo C Noor H Hing H L\& Sri P A. Decomposition Process and Post Mortem Changes: Review. Sains Malaysiana 2014; 43(12): 1873-1882.

31. Tice R., Agurell E., Anderson D., Burlinson B., Hartmann A., Kobayashi H., Miyamae Y., Rojas E., Ryu J, Sasaki Y: Single cell gel/ Comet Assay: Guidelines for in vitro and in vivo genetic toxicology testing. Environ. Mol. Mutagen 2000, 35; 206-221.

32. Yun L, John C, Chih-Yuan H Yong : Agarose Gel Electrophoresis for the Separation of DNA Fragments. Journal of Visualized Experiments 2012 e3923, doi: 10.3791/3923.

33. Zhen J, Zhang X D, Niu Q. Relationship between the postmortem interval and nuclear DNA changes of Heart muscular cells in mice. Fa Yi XueZaZhi. 2006; 22:173-176.

34. Zheng J, Li X, Shan D, et al. DNA degradation within mouse brain and dental pulp cells $72 \mathrm{~h}$ post-mortem. Neural Regen Res. 2012; 7:290-294. 